\title{
Characteristics of Oropharyngeal Candida and Bacterial Colonization in Cancer Patients
}

\author{
Filiz C. SENLER ${ }^{1}$, Sefik CAKMAKCI ${ }^{1}$, Ozay A. AKAN², Ahmet DEMIRKAZIK', \\ Hakan AKBULUT ${ }^{1}$, Fikri ICLI ${ }^{1}$ \\ 'Ankara University Medical Faculty, Medical Oncology Department, Ankara, Turkey \\ ${ }^{2}$ Ankara University Medical Faculty, Central Laboratory, Ankara, Turkey
}

\begin{abstract}
Changes occur in the oropharyngeal flora of the cancer patients due to disease and treatment related factors. In this study, bacterial and candidal colonizations were evaluated in 119 cancer patients from the two clinics (Ibni Sina Hospital is old clinic and Cebeci Hospital is new clinic) of the Medical Oncology Department of Ankara University Medical Faculty. Throat swabs and cultures were obtained from all patients on days 0,4 and 7 of admission. The clinical parameters that can effect colonization like age, sex, use of steroids and antibiotics, chemotherapy, catheterization/TPN (total parenteral nutrition) procedures, ECOG performance status and number of admissions were recorded. The distribution of detected microorganisms and the differences in subsequent days were evaluated. There were no significant differences between two hospitals with regard to bacterial and candidal colonizations on the 1st, 4th and 7th days. The performance status, catheterization/TPN procedures, usage of antibiotics and chemotherapy are found to be the significant clinical parameters that can effect colonizations.
\end{abstract}

Keywords: Oropharyngeal colonization, Cancer, Surveillance

\section{ÖZET}

\section{Kanser Hastalarında Orofaringeal Kandida ve Bakteriyel Kolonizasyonun Özellikleri}

Kanser hastalarında hastalığa ve tedavilere bağlı faktörler nedeniyle, orofaringeal florada değişiklikler olmaktadır. Bu çalışmada, Ankara Üniversitesi Tıp Fakültesi Tıbbi Onkoloji Bilim Dalı'nın iki kliniğinden (Ibni Sina Hastanesi ve Cebeci Hastanesi) toplam 119 hastada bakteriyel ve kandida kolonizasyonları incelendi. Illk 24. saatte, 4.gün ve 7.günde boğazdan sürveyans kültürü amaçIı sürüntü alındı. Yaş, cinsiyet, steroid, antibiyotik kullanımı, kemoterapi, kateter/total parenteral nütrisyon uygulamaları, ECOG performans statusu ve daha önceki yatış sayısı gibi kolonizasyonu etkileyebilecek klinik parametreler kaydedildi. Saptanan mikroorganizmaların dağlımına, günlere göre değişikliğine bakıldı. İbni Sina ve Cebeci Hastaneleri arasında hem bakteriyel hem de kandida kolonizasyonu açısından 1, 4. ve 7. günlerde anlamlı farkllık saptanmadı. Kolonizasyonu etkilediği belirlenen en önemli klinik özellikler performans statusu, kateter-TPN (total parenteral nütrisyon), antibiyotik ve kemoterapi kullanımı idi.

Anahtar Kelimeler: Orofaringeal kolonizasyon, Kanser, Sürveyans 


\section{INTRODUCTION}

Colonization is defined as the presence and multiplication of a microorganism in the host without any clinical findings and immune reaction at the time of isolation. Actually, colonization is a normal physiologic event. Colonization is important because it may turn into infection in situations like cancer, where immune system is suppressed. In patients with cancer, especially when they were admitted to the hospital, colonization is easy and with the predisposing factors, infections and sepsis leading to serious morbidity and mortality occurs. ${ }^{1.2}$

In cancer patients colonization occurs in oropharynx as well as gastrointestinal system, urinary system and airways. Colonization starts within 48 hours of hospitalization. $^{3}$

Through the certain types of microbial flora of hospitals and health workers, these immune suppressed patients are colonized with different types of candida and bacteria. ${ }^{48}$ The most frequent site of colonization is the oropharynx which allows easy access to the clinicians to take samples. Most of the time, colonization is necessary before infection. Best examples for this situation are methicillin resistant Staphylocooccus aureus (MRSA), C. difficile, candida species and vancomycin-resistant enterococcus which are the most frequent nosocomial pathogens of infection.-11 In addition undiscovered colonized patients are like a reservoir in the hospital and they easily contaminate the other patients. The two most important factors increasing the colonization rate are the duration of hospitalization and the severity of disease. ${ }^{3}$ In relation with this situation the frequency of procedures like urinary catheter placement, tracheostomy, nasogastric tubes, presence of fistulas or mucosa-skin lesions, pulmonary aspirations and hemodialysis lead to nosocomial infections. ${ }^{12}$ Moreover, administration of broad spectrum antibiotics and steroids, chemotherapy and radiotherapy increase colonization rates. ${ }^{3}$

The aim of survey used in hospitals is to determine the nosocomial infections. However, evaluation of cultures obtained in surveillance is especially inconclusive for oropharyngeal colonization. Because colonization does not always lead to infection and sepsis, there are difficulties in rationalizing the clinical importance and cost of these data.

In this trial, we aimed to investigate the oropharyngeal colonization of patients with cancer who were admitted to the hospital and exposed to the microbial flora of the hospital, to determine the bacterial and candidal agents and possible risk factors leading to colonization. Additionally, we aimed to compare the colonizations at the newly established clinic at the Cebeci Hospital and the old clinic at Ibni Sina hospital. This was the first surveillance at Cebeci Hospital.

\section{PATIENTS AND METHODS}

In the present study, candida and bacterial infections in cancer patients who had been hospitalized for at least 7 days at the medical oncology departments of Ibni Sina and Cebeci hospitals of Ankara University Medical Faculty were investigated. Within a sixmonth period between October 2003 and April 2004, 119 consecutive patients (57 from Ibni Sina Hospital and 62 from Cebeci Hospital) were included.

From the hospitalized patients, throat swabs and cultures were obtained on days 1,4 and 7. These samples were examined at the microbiology unit of the central laboratory of Ibni Sina Hospital. Typing was done in cases of growth on bacterial and candidal cultures. For the identification of types of microorganisms colonized in the throat with standard microbiological methods, API automatically identification method was used. Little, medium and high semiquantitative evaluations were done for the growth level of up to 10,11 to 50 and more than 51 colonies respectively.

Statistical evaluation: Chi-square test was used for the comparison of colonization rates of Ibni Sina and Cebeci clinics on the 1st, 4th and 7th days. Logistic regression analysis was used to evaluate the role of clinical parameters in colonization. Only the parameters having the $\mathrm{p}$ values less than 0.250 in univariate analysis were included in multivariate logistic regression analysis to determine the independent parameters affecting the colonization rates of the microorganisms.

\section{RESULTS}

Patient characteristics: A total of 119 patients including 57 patients from Ibni Sina and 62 patients from Cebeci hospitals were included in the study. Patient characteristics are shown in Table 1. Patients in both clinics were evaluated for risk factors that can effect colonization. Patients were compared with regard to performance status, usage of steroids and antibiotics (taken in the last 2 weeks or during the hospitalization), number of admissions (hospitalizations longer than 3 days), chemotherapy (during hospitalization or within the last 3 weeks), catheterization/TPN procedures and radiotherapy to head and neck area (within the last 6 months). Findings were summarized in Table 2. 


\begin{tabular}{|c|c|c|c|}
\hline Parameter & Ibni Sina Hospital n (\%) & Cebeci Hospital n (\%) & Total \\
\hline Number of the patients & 57 & 62 & 119 \\
\hline \multicolumn{4}{|l|}{ Gender } \\
\hline Male & $30(53)$ & $40(65)$ & $70(59)$ \\
\hline Female & $27(47)$ & $22(35)$ & $49(41)$ \\
\hline \multicolumn{4}{|l|}{ Age } \\
\hline$\geq 50 \mathrm{yrs}$ & $21(37)$ & $35(56)$ & $56(47)$ \\
\hline$<50$ yrs & $36(63)$ & $27(44)$ & $63(53)$ \\
\hline \multicolumn{4}{|l|}{ Cancer types } \\
\hline Gastrointestinal & 5 (8) & $14(23)$ & $19(16)$ \\
\hline Lung & $3(6)$ & $17(27)$ & $20(17)$ \\
\hline Head and Neck & $4(7)$ & $6(9)$ & $10(8)$ \\
\hline Lymphoma & $14(25)$ & $5(9)$ & $19(16)$ \\
\hline Others & $31(54)$ & $20(32)$ & $51(43)$ \\
\hline
\end{tabular}

General colonization rates: Three hundred fifty four oropharyngeal surveillance culture specimens had been obtained from 119 patients. One hundred seventy eight bacteria/fungi including candida, gram negative bacillus, S. Aureus and non-fermentative bacteria were isolated from surveillance culture specimens and 200 cultures were negative. The total number of Candidal colonization 111 (C. albicans 69, C. glabrata 10, C. kefyr 3, C. spp 11, C. dublinensis 7, C. tropicalis 4, C.parapsilosis 1, C. crusei 3 and C. halmi 3). Bacteria were isolated in 67 . The bacterial colonization rates were $15 \%$ for Ibn-i Sina Hospital and $21 \%$ for Cebeci Hospital, candidal colonization rates were $26 \%$ and $36 \%$, respectively. The

\begin{tabular}{|llll|}
\hline \multicolumn{4}{|l|}{ Table 2. Patient characteristics according to the clinics. } \\
\hline Parameter & Ibni Sina Hospital n (\%) & Cebeci Hospital n (\%) & p \\
\hline Antibiotic use & $16(28)$ & $29(46)$ & 0.030 \\
Steroid use & $7(12)$ & $15(24)$ & 0.105 \\
Catheterization/TPN & $5(8)$ & $15(24)$ & 0.020 \\
No. of hospital admissions & & & \\
0 to 2 & $31(54)$ & $46(74)$ & 0.010 \\
$\geq 3$ & $26(46)$ & $16(26)$ & \\
PS & & $26(41)$ & 0.0001 \\
0-2 & $43(75)$ & $36(59)$ & 0.106 \\
3-4 & $14(25)$ & $38(61)$ & 0.397 \\
Chemotherapy & $43(75)$ & $14(22)$ & \\
Radiotherapy & $10(17)$ & & \\
\hline TPN: total parenteral nutrition, PS: performance status & & \\
\hline
\end{tabular}


Table 3. The colonization rates of the isolated microorganisms in Ibni sina and Cebeci Hospitals.

\begin{tabular}{|llll|}
\hline Colonization type/ day & ilbni Sina Hospital $n(\%)$ & Cebeci Hospital $n(\%)$ & $p$ \\
\hline Bacterial/ day 1 & $6(10,5)$ & $10(16,1)$ & 0,371 \\
Bacterial/ day 4 & $8(14,0)$ & $17(27,0)$ & 0,073 \\
Bacterial/ day 7 & $11(19,3)$ & $20(32,3)$ & 0,108 \\
Candidal/ day 1 & $22(38,6)$ & $29(46,8)$ & 0,368 \\
Candidal/ day 4 & $14(24,6)$ & $21(33,9)$ & 0,266 \\
Candidal/ day 7 & $9(15,8)$ & $17(27,4)$ & 0,432 \\
\hline
\end{tabular}

colonization rates are shown in Table 3 . There were no significant differences between Ibni Sina and Cebeci Hospitals with regard to bacterial and candidal colonizations on day 1,4 and 7.

The trends of the colonization rates of the isolated microorganisms within a week from the patients in both hospitals are shown in Figure 1-3.

The effects of clinical parameters on colonization of the microorganisms: We studied the clinical parameters that might affect the colonization of the microorganisms in patients with cancer hospitalized in the Ibni Sina and Cebeci hospitals of Ankara University (Table 4 and 5).

Poor performance status and the intravenous catheter/TPN have been found to be significantly correlated with increased bacterial colonization rates on days 4 and 7 in Cebeci hospital (Table 4). However, while no significant clinical parameter correlating with bacterial colonization on day 4 in Ibni Sina Hospital, only performance status correlated on day 7 (Table 4).

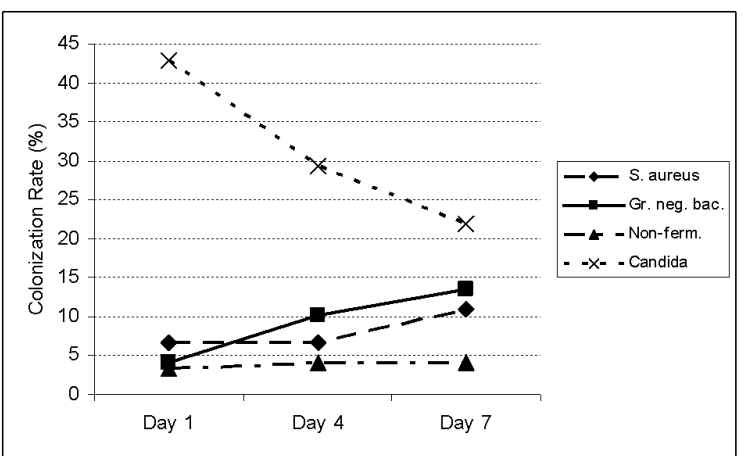

Figure 1. The distribution of the colonization rates of isolated microorganisms in both hospitals (Gr. neg. bac.: gramnegative bacilli, Non-ferm.: non-fermentative bacteria).
In the multivariate logistic regression analysis the poor performance status was found to be a significant parameter affecting the bacterial colonization rates on day 7 in both hospitals (Table 6). Likewise, the intravenous catheter/TPN was also a significant parameter for bacterial colonization rates on days 4 and 7 in Cebeci Hospital (Table 6).

While there was no significant parameter affecting the candida colonization rate on day 4 in Ibni Sina Hospital, the performance status, antibiotic use and chemotherapy were the significant parameters on day 7 in univariate analysis (Table 5). However, only the antibiotic use was found to be significantly correlated with candidal colonization rates on days 4 and 7 in Cebeci Hospital (Table 5).

The multivariate logistic regression analysis yielded the performance status as the significant parameter for candida colonization rate on day 7 in Ibni Sina Hospital and antibiotic use on days 4 and 7 in Cebeci Hospital (Table 6).

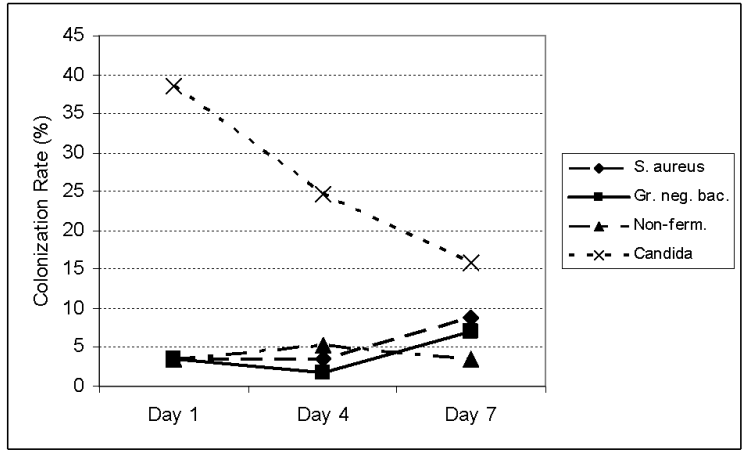

Figure 2. The colonization rates of the isolated microorganisms in Ibni Sina Hospital (Gr. neg. bac.: gram-negative bacilli, Non-ferm.: non-fermentative bacteria). 


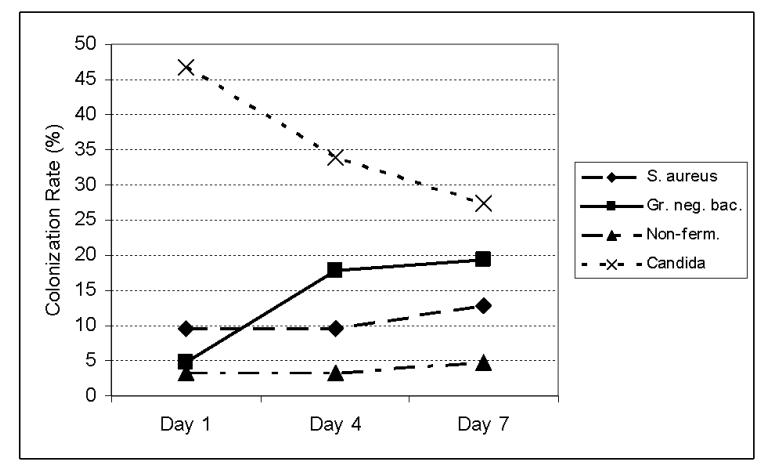

Figure 3. The colonization rates of the isolated microorganisms in Cebeci Hospital (Gr. neg. bac.: gram-negative bacilli, Non-ferm.: non-fermentative bacteria).

\section{DISCUSSION}

In this trial, we isolated $\mathrm{S}$. Aureus, gram-negative bacilli, candida species and non-fermentative bacteria which are not found in normal flora of healthy people from the throat surveillance cultures of cancer patients hospitalized in Ibni Sina and Cebeci Hospitals of Ankara University. Although the first colonization has been expected following 48-72 hours of hospitalization, we found positive cultures in $35 \%$ of the patients within first day of hospitalization (early colonization). There were gastrointestinal obstruction in 3 patients and tracheostomy in 3 patients with early colonization. Other factors existed in the pre-hospitalization period might also affect the early colonization.
Previously, two studies have been reported about colonization in Ibni Sina Hospital. The study in 1991 (Dinçol, et al.) examined the microbial colonization of 118 patients with infection. Thirty bacterial colonization were identified in 110 throat swabs and cultures obtained from 77 patients. ${ }^{1}$ This higher rate than the finding from our study may be due to higher rate of neutropenic patients. Neutropenia increases the colonization..$^{13,14}$ In the study in 2002 candida colonization has been investigated in 543 hospitalized patients and 209 candida species were isolated. While $70 \%$ of the isolates were C. albicans, no C. dublinensis could be isolated. ${ }^{2}$ In our study, 111 candida species have been isolated from 119 patients and $45 \%$ of them were nonalbicans species. Also, 7 (6\%) C. dublinensis colonization has been identified. High rate of fluconazole and amphotericin B use in immunosuppressed patients had been suggested to explain the shift from $C$. albicans to nonalbicans species. ${ }^{14}$ Our data supports this explanation. The clinical parameters that can increase colonization includes performance status, usage of antibiotics, chemotherapy and catheterization/TPN procedures. Although advanced age had been reported to increase the colonization of gram-negative bacilli, effect of age was not observed in our study..$^{15}$ In many studies, radiotherapy to head and neck tumors has been reported as a major cause of colonization. ${ }^{16}$ In our study, the number of patients with head and neck tumors who received radiotherapy was nine and majority of them had received radiotherapy before six months.

Table 4. The effects of clinical parameters on bacterial colonization in both hospitals ( $p$ values, univariate analysis).

\begin{tabular}{|c|c|c|c|}
\hline Parameters & Ibni Sina Hospital & Cebeci Hospital & \\
\hline & Day 4 & Day 7 & Day 4Day 7 \\
\hline Age & 0.394 & 0.866 & 0.3560 .331 \\
\hline PS & 0.071 & 0.018 & 0.0200 .014 \\
\hline Steroid use & 0.250 & 0.720 & 0.9400 .919 \\
\hline Antibiotic use & 0.522 & 0.948 & 0.0820 .370 \\
\hline Chemotherapy & 0.438 & 0.400 & 0.9330 .971 \\
\hline No. of hospital admissions & 0.706 & 0.427 & 0.1410 .107 \\
\hline Radiotherapy & 0.136 & 0.340 & 0.2940 .078 \\
\hline Catheterization /TPN & 0.344 & 0.967 & 0.0200 .001 \\
\hline
\end{tabular}

PS: Performance Status, TPN: Total Parenteral Nutrition 


\begin{tabular}{|c|c|c|c|c|}
\hline Parameters & Ibni Sina Hospital & Cebeci Hospital & & \\
\hline & Day 4 & Day 7 & Day 4 & Day 7 \\
\hline Age & 0.706 & 0.695 & 0.943 & 0.734 \\
\hline PS & 0.067 & 0.001 & 0.937 & 0.732 \\
\hline Steroid use & 0.792 & 0.304 & 0.229 & 0.210 \\
\hline Antibiotic use & 0.156 & 0.046 & 0.020 & 0.021 \\
\hline Chemotherapy & 0.106 & 0.030 & 0.798 & 0.506 \\
\hline No. of hospital admissions & 0.594 & 0.969 & 0.250 & 0.568 \\
\hline Radiotherapy & 0.311 & 0.245 & 0.384 & 0.801 \\
\hline Catheterization /TPN & 0.054 & 0.787 & 0.565 & 0.213 \\
\hline
\end{tabular}

This study is the first study, which compares a newly established clinic with an old clinic, and changes in the oropharyngeal flora of cancer patients and effects of various clinical parameters were examined and no difference could be identified.

\section{REFERENCES}

1. Willke A, Dinçol D, Demirkazık A, ve ark. Kanser Hastalarında infeksiyon ataklarının, infeksiyon düşündüren dönemlerin ve mikrobiyal kolonizasyonların değerlendirilmesi. UHOD 3: 162-168, 1992.

2. Tekeli A, Dolapçi A, Cesur S, et al. Candida dublinensis studies and isolation of Candida types in oropharyngeal specimens from oncologic patients. Mikrobiyol Bul 36: 57-63, 2002.

Table 6. The significant parameters affecting the colonization rates of the microorganisms in both clinics (logistic regression analysis).

\begin{tabular}{|c|c|c|}
\hline $\begin{array}{l}\text { Hospital Colonization type/day } \\
\text { Parameters }\end{array}$ & $\begin{array}{l}\text { Odds Ratio } \\
\text { (95\% Confidence Intervals) }\end{array}$ & $\mathbf{p}$ \\
\hline \multicolumn{3}{|l|}{$\begin{array}{l}\text { Ibni Sina Hospital } \\
\text { Bacterial/day } 7\end{array}$} \\
\hline PS & $5.70(1.39-23.36)$ & 0.016 \\
\hline $\begin{array}{l}\text { Candida/day } 7 \\
\text { PS }\end{array}$ & Candida/day 7 & 0.009 \\
\hline $\begin{array}{l}\text { Cebeci Hospital } \\
\text { Bacterial/day } 4 \\
\text { Catheterization/TPN }\end{array}$ & $5.86(1.46-23.52)$ & 0.013 \\
\hline \multicolumn{3}{|l|}{ Bacterial/day 7} \\
\hline \multicolumn{3}{|l|}{ Candidal/day 4} \\
\hline Antibiotic use & $4.07(1.25-13.23)$ & 0.019 \\
\hline \multicolumn{3}{|l|}{ Candidal/day 7} \\
\hline Antibiotic use & $3.47(1.00-12.01)$ & 0.050 \\
\hline
\end{tabular}


3. Jarvis WR. Epidemiology of nosocomial fungal infections, with emphasis on Candida species.Clin Infect Dis 26: 1526-30, 1995.

4. Richet HM, Andremont A, Tancrede C, et al. Risk factors for candidemia in patients with acute lymphocytic leukemia. Rev Infect Dis 13: 211-15, 1991.

5. Krupova Y, Sejnova D, Dzatkova J, et al. Prospective study on fungemia in children with cancer: analysis of 35 cases and comparison with 130 fungemias in adults. Support Care Cancer 8: 427-30, 2000.

6. Luzzati R, Amalfitano G, Lazzarini L, et al. Nosocomial candidemia in non-neutropenic patients at an Italian tertiary care hospital. Eur J Clin Microbiol Infect Dis 19: 602-607, 2000.

7. Lark RL, Chenoweth C, Saint S, et al. Four year prospective evaluation of nosocomial bacteremia: epidemiology, microbiology, and patient outcome. Diag Microbiol Infect Dis 38: 131-140, 2000.

8. Asensio A, Guerrero A, Queredal, et al. Colonization and infection with methicillin-resistant Staphylococcus aureus: associated factors and eradication. Infect Control Hosp Epidemiol 17: 20-28, 1996.

9. Bagg J, Sweeney MP, Lewis MA et al. High prevalence of non-albicans yeasts and detection of anti-fungal resistance in the oral flora of patients with advanced cancer, Palliat Med 17: 477-481, 2003.

10. Jarvis WR.The Epidemiology of Colonization. Infect Control Hosp Epidemiol 17: 47-52, 1996.

11. Safdar A, Maki D. The commonality of risk factors for nosocomial colonization and infection with antimicrobial-resistant S.aureus, Enterococcus, Gram-Negative Bacilli,C.Difficile and Candida. Annals of Int Medicine, 136: 834-844, 2002.

12. Thomas S, Raman R, Idikula J et al. Alterations in oropharyngeal flora in patients with a nasogastric tube: a cohort study. Crit Care Med 20: 1677-80, 1992.
13. Martino P, Girmenia C, Micozzi A, et al. Prospective study of Candida colonization, use of empiric amphotericin B and development of invasive mycosis in neutropenic patients. Eur J Clin Microbiol Infect Dis. 13: 797-804, 1994.

14. Amar S, Vishinu C, Emily W, et al. Prospective study of candida species in patients at a comprehensive cancer center. Antimicrobial Agents and Chemotherapy 45: 2129-2133, 2001.

15. Hiar I, Tande D, Gentric A, et al. Oropharyngeal colonization by Gram-negative bacteria in elderly hospitalized patients: incidence and risk factors. Rev Med Intern 23: 4-8, 2002.

16. Spencer W, Redding R, Zellars C, et al. Epidemiology of oropharyngeal candida colonization and infection in patients receiving radiation for head and neck cancer. Journal of Clinical Microbiology 37: 3896-3900, 1999.

\section{Correspondence}

Dr. Filiz Çay ŞENLER

Ankara Üniversitesi Tıp Fakültesi

Medikal Onkoloji Bölümü

Cebeci Hastanesi

ANKARA / TURKEY

Tel: (+90.312) 5957115

Fax: (+90.312) 3192283

e-mail: senler@medicine.ankara.edu.tr 